Tribhuvan University Journal

Vol. 35, No. 2: 1-11, December, 2020

Research Directorate, Tribhuvan University,

Kathmandu, Nepal

DOI: https://doi.org/10.3126/tuj.v35i2.36183

\title{
PHYTOCHEMICAL SCREENING OF MEDICINAL PLANTS AND STUDY OF THE EFFECT OF PHYTOCONSTITUENTS IN SEED GERMINATION
}

\author{
Tinky Sharma ${ }^{1}$, Binjita Pandey ${ }^{2}$ Bishnu Kumar Shrestha ${ }^{3}$, \\ Gayatri Maiya Koju ${ }^{3}$, Rojeena Thusa ${ }^{4}$, Nabin Karki ${ }^{5 *}$ \\ ${ }^{I}$ Central Department of Chemistry, Kirtipur, TU. \\ ${ }^{2}$ Tri-Chandra Multiple Campus, Kathmandu, TU. \\ ${ }^{3}$ Lecturer, Bhaktapur Multiple Campus, Bhaktapur, TU. \\ ${ }^{4}$ Lecturer, Khwopa College, Bhaktapur. \\ ${ }^{5}$ Reader, Bhaktapur Multiple Campus, Bhaktapur, TU. \\ *Corresponding author: nabin.karki@bkmc.tu.edu.np
}

\begin{abstract}
Phytochemical screening of ten different locally available plant parts was done in methanol extract. Tannin, quinine, terpenoid, flavonoid, steroid, alkaloid, cardiac glycoside, glycoside, volatile oils, etc were the phytoconstituents found in plants. The study of the effect of phytoconstituents in the germination of Pisum sativum seeds revealed that the phytoconstituents present in plant extracts showed the cytotoxic effect in living cells i.e. in germinating Pisum sativum seeds. The phytoconstituents present in the plant extract showed an effect on cell proliferation and growth. Hence these plants could be used to develop drugs against cancer cells and also may be effective against microbes and bacteria.
\end{abstract}

Keywords: phytochemical screening - phytoconstituents - cyto-toxicity - methanol extract - seed germination

\section{INTRODUCTION}

Medicinal plants are important species of plants that according to the traditional medicinal practices and also from modern scientific studies are useful for medicinal purposes to alleviate diseases, make human health more invigorating. These plants are contemplated as rich sources of ingredients that can be used in the synthesis and production of drugs (Oladeji et al. 2019). Plants consist of various kinds of chemical constituents known as phytoconstituents (Mercy et al. 2017). Phytoconstituents 
serve the plants by contributing some secondary functions like; helps in plant growth, safeguarding the plants by activating defense mechanism, imparting color, odor, and flavor to the plants (Molyneux et al. 2007). Natural products and their derivatives exhibit minimal side effects and improved efficacy than other synthetic counterparts (Batiha et al. 2020). These plant-derived components like flavonoids, quinine, terpenoid, etc conduct certain biological functions that enhance therapeutic activities such as anti-carcinogenic, anti-mutagenic, anti-inflammatory, and antioxidant properties (Batiha et al. 2020). Phytochemical screening is the scientific process of analyzing, examining, extracting, experimenting, and thus identifying different classes of phytoconstituents present in various parts of the base for the discovery of drugs, the active components could be further taken for investigation and research. The process was qualitative which is termed phytochemical screening. The outcome of the research could be fruitful in developing potent drugs against various diseases.

Table 1: List of medicinal plants and uses

\begin{tabular}{|c|c|c|c|}
\hline Name & Part taken & Local name & Local uses \\
\hline$\overline{\text { Allium cepa (ACB) }}$ & Bulb & Onion & Vegetable. \\
\hline $\begin{array}{l}\text { Curcuma longa } \\
\text { (CLR) }\end{array}$ & Rhizome & Turmeric & $\begin{array}{l}\text { Antiseptic, anti-diabetic } \\
\text { and antibacterial agent. } \\
\text { (Maithalikarpagaselvi et al. 2020) }\end{array}$ \\
\hline $\begin{array}{l}\text { Ocimum sanctum } \\
\text { (OSL) }\end{array}$ & Leaves & Tulsi & $\begin{array}{l}\text { Antioxidant, Anti-inflammatory } \\
\text { (Chaudhary et al. 2020) }\end{array}$ \\
\hline $\begin{array}{l}\text { Mentha arvensis } \\
\text { (MAL) }\end{array}$ & Leaves & Mint & $\begin{array}{l}\text { As an antibacterial, and an antiseptic } \\
\text { agent. (Patil et al. 2016) }\end{array}$ \\
\hline $\begin{array}{l}\text { Allium sativum } \\
\text { (ASB) }\end{array}$ & Bulb & Garlic & Antioxidant. (Melania et al. 2019) \\
\hline $\begin{array}{l}\text { Zingiber officinale } \\
(\mathrm{ZOR})\end{array}$ & Rhizome & Ginger & $\begin{array}{l}\text { Treats cold, cough, in gastric } \\
\text { problems (Arwande et al. 2018) }\end{array}$ \\
\hline $\begin{array}{l}\text { Acorus calamus } \\
\text { (ACR) }\end{array}$ & Rhizome & Calamus & $\begin{array}{l}\text { To treat throat problems and stomach } \\
\text { problems. (Nath \& Yadav, 2016) }\end{array}$ \\
\hline $\begin{array}{l}\text { Zanthoxyllum } \\
\text { armatum }\end{array}$ & Seeds & Timur & $\begin{array}{l}\text { Used in intestinal problems. (Bharti \& } \\
\text { Bhushan 2015) }\end{array}$ \\
\hline (ZAS) & & & \\
\hline (NAL) & Leaves & Parijat & Anti-diabetic. (Haque et al. 2015) \\
\hline $\begin{array}{l}\text { Nyctanthes } \\
\text { arbortristis } \\
\text { (NAF) }\end{array}$ & Flowers & Parijat & $\begin{array}{l}\text { Anti-diabetic, treats hypertension. } \\
\text { (Haque et al. 2015) }\end{array}$ \\
\hline
\end{tabular}


The aim of this study is the phytochemical screening of plants and cytotoxic activity of phytoconstituents in living cells. Plants used for the study along with their local name, parts taken, and local use are shown in Table 1. The study is important because plants showing cytotoxic effect in living cells could be further investigated and specifically studied for developing drugs against cancer and also may be against microbes and bacteria. Curcumin present in turmeric has reported anticancer properties (Carroll, et al. 2011). Fruits and vegetables containing flavonoids showed cancer chemo-preventive activity (Mishra, et al. 2013). The presence of classes of phytochemicals as such; flavonoid, alkaloid, tannin showed cytotoxic effect (Chaudhary, et al. 2017).

\section{MATERIALS AND METHODS}

Ten different plant samples were identified and collected. Palanshe, Bhaktapur was selected for the collection of plants for the study purpose which is located in Suryavinayak Municipality, Bhaktapur district, Bagmati province of Nepal and is situated at an altitude of $1412 \mathrm{~m}$ height with latitude $85^{\circ} 27^{\prime} 32^{\prime \prime}$ east and longitude $27^{\circ} 38^{\prime} 42^{\prime \prime}$ north. The climate of the village is moderate with deciduous vegetation. The plants were collected in October 2017.

Collected plant parts were washed with distilled water, cut into small pieces, and dried in shade for 4 weeks. Dried plant parts were ground into fine powder using an electric grinder. $100 \mathrm{~g}$ of each powdered sample was soaked in 100-150 mL methanol in a conical flask, shaken occasionally to mix, and macerated for 72 hours at room temperature. Maceration intends to soften and break the plant's cell wall to release the soluble phytoconstituents (Handa et al. 2008). All the laboratory activities were performed in the laboratory of the Department of Chemistry, Bhaktapur Multiple Campus. Ohaus AR3130 electronic analytical balance was used for weighing the powdered sample and chemicals in the experiments. Then the solution was percolated through cotton. Filtrate and marc were obtained.

Phytochemical screening: The prepared extract of all the ten plants was used to test various phytoconstituents present in them. Different chemical reagents were prepared and specific test, for specific phytochemicals was done. These various tests were qualitative and hence termed phytochemical screening. All chemicals and solvents were procured from Fisher Scientific, India, and were used without further purification. The tests were done by following standard procedures based on journal articles. (Alamzed et al. 2013), (Thusa \& Mulmi, 2017), and (Talukdar \& Chaudhary, 2010). 
Test for tannin / polyphenol (Talukdar \& Chaudhary, 2010): To the diluted extract, 3-4 drops of $10 \% \mathrm{FeCl}_{3}$ were added, blue color was seen for gallic tannins and the presence of catechol tannin turned the solution green.

Test for reducing sugar (Thusa \& Mulmi, 2017): To $0.5 \mathrm{~mL}$ of plant extract, $1 \mathrm{~mL}$ of water, and 5-8 drops of Fehling's solution were added and heated. The presence of reducing sugar was indicated by the appearance of brick red precipitation.

Test for quinine (Thusa \& Mulmi, 2017): To the extract, freshly prepared $\mathrm{FeSO}_{4}$ solution $(1 \mathrm{~mL})$ and ammonium thiocyanate were added then conc. $\mathrm{H}_{2} \mathrm{SO}_{4}$ was added drop by drop. The deep red color indicated the presence of quinine.

Test for glycosides (Alamzed et al., 2013): Molisch's Reagent Test: To the extract, $5 \mathrm{~mL}$ Molisch's reagent and concentrated $\mathrm{H}_{2} \mathrm{SO}_{4}$ were added. Violet color indicated glycosides.

Test for flavonoids (Talukdar \& Chaudhary, 2010): Shinoda test: $4 \mathrm{~mL}$ of extract solution, $1.5 \mathrm{~mL}$ of $50 \%$ methanol solution a small magnesium chunk were warmed. 5-6 drops of concentrated $\mathrm{HCl}$ were added, red color was observed for flavonoids.

Dil. $\mathrm{NH}_{3}$ test: $5 \mathrm{~mL}$ of dilute $\mathrm{NH}_{3}$ solution in the extract was taken with the addition of conc. $\mathrm{H}_{2} \mathrm{SO}_{4}$. The appearance of yellow-colored precipitation indicated flavonoids.

Test for terpenoids (Alamzed, et al. 2013): $0.2 \mathrm{~g}$ of each sample was mixed with $2 \mathrm{~mL}$ chloroform, $3 \mathrm{~mL}$ conc. $\mathrm{H}_{2} \mathrm{SO}_{4}$. Reddish-brown coloration indicated the presence of terpenoids.

Test for alkaloids: Meyer's test (Talukdar \& Chaudhary, 2010): To 2 $\mathrm{mL}$ of extract, $1 \mathrm{~mL}$ of Meyer's reagent was added. The presence of pale yellow precipitate indicated the presence of alkaloids.

Dragendroff's reagent test (Alamzed et al. 2013): $2 \mathrm{~mL}$ of extract was warmed with $2 \% \mathrm{H}_{2} \mathrm{SO}_{4}$. Few drops of Dragendroff's reagent were added. Orange-red precipitate indicated the presence of alkaloids.

Test for saponins (Alamzed et al. 2013): $2 \mathrm{~g}$ of powdered sample was boiled in $20 \mathrm{~mL}$ of distilled water. $10 \mathrm{~mL}$ of filtrate, $5 \mathrm{~mL}$ of distilled water were quivered vigorously. The appearance of frothing indicated the presence of saponins.

Test for volatile oils (Talukdar \& Chaudhary, 2010): $2 \mathrm{~mL}$ extract was shaken with $0.1 \mathrm{~mL}$ of $\mathrm{NaOH}$ and a small quantity of dilute $\mathrm{HCl}$. White precipitate indicated the presence of volatile oil. 
Test for cardiac glycosides (Talukdar \& Chaudhary, 2010): $5 \mathrm{~mL}$ of plant extract was treated with $2 \mathrm{~mL}$ of glacial acetic acid with one drop of $\mathrm{FeCl}_{3}$ solution. A violet ring may appear or a greenish ring may form just which showed the presence of cardiac glycosides.

Test for steroids (Talukdar \& Chaudhary, 2010): $1 \mathrm{~g}$ of plant extract was dissolved in a few drops of acetic acid and a drop of conc. $\mathrm{H}_{2} \mathrm{SO}_{4}$ was added. The appearance of green color indicated the presence of steroids.

\section{Study of effect in seed germination}

Germinating Pisum seeds were taken as the representative of living cells which was the basis to study the cytotoxic activity of phytoconstituents in living cells. The study of the effect of phytoconstituents in the germination of Pisum seed was done in aqueous extract, methanol extract, and methanol by soaking in the solutions for five days. The method implied was based on procedures given by (Radwan et al. 2019), (Hassan \& Samy, 2007), (Chekuboyina \& Rao 2015).

\section{RESULTS AND DISCUSSION}

Table 2: Phytochemical screening of different medicinal plants

\begin{tabular}{|c|c|c|c|c|c|c|c|c|c|c|c|c|c|}
\hline \multirow[b]{3}{*}{$\begin{array}{l}\text { Plant } \\
\text { extract }\end{array}$} & \multicolumn{13}{|c|}{ Phytochemical Screening } \\
\hline & \multirow[b]{2}{*}{ 咅 } & \multirow[b]{2}{*}{ 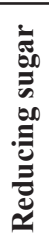 } & \multirow[b]{2}{*}{ 兽 } & \multirow[b]{2}{*}{$\begin{array}{l}\stackrel{0}{0} \\
\frac{0}{0} \\
\frac{2}{0} \\
0\end{array}$} & \multicolumn{2}{|c|}{ Flavonoid } & \multirow[b]{2}{*}{ 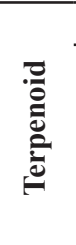 } & \multicolumn{2}{|c|}{ Alkaloid } & \multirow[b]{2}{*}{ 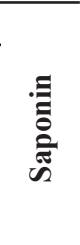 } & \multirow[b]{2}{*}{ 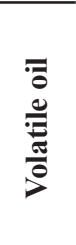 } & \multirow[b]{2}{*}{ 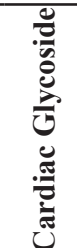 } & \multirow[b]{2}{*}{$\frac{\mathscr{0}}{0}$} \\
\hline & & & & & 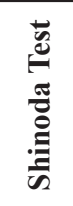 & 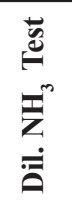 & & 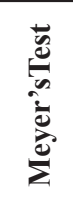 & 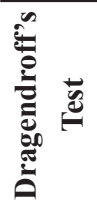 & & & & \\
\hline$\overline{\mathrm{ACB}}$ & - & - & +++ & +++ & +++ & $\overline{+++}$ & +++ & - & - & + & +++ & + & + \\
\hline CLR & +++ & _- & +++ & +++ & +++ & +++ & +++ & +++ & +++ & ++ & +++ & +++ & ++ \\
\hline OSL & +++ & _ & +++ & +++ & ++ & ++ & +++ & +++ & +++ & ++ & +++ & +++ & +++ \\
\hline MAL & +++ & - & +++ & +++ & +++ & +++ & +++ & +++ & +++ & ++ & +++ & +++ & +++ \\
\hline ASB & - & - & +++ & +++ & + & + & +++ & - & - & + & +++ & + & + \\
\hline ZOR & +++ & _ & +++ & +++ & +++ & +++ & +++ & +++ & +++ & +++ & +++ & +++ & - \\
\hline $\mathrm{ACR}$ & - & - & +++ & +++ & + & ++ & +++ & +++ & +++ & +++ & +++ & +++ & + \\
\hline ZAS & +++ & + & +++ & ++ & +++ & +++ & +++ & +++ & +++ & & +++ & ++ & ++ \\
\hline NAL & +++ & & +++ & +++ & ++ & ++ & +++ & +++ & +++ & $+\overline{+}+$ & ++ & +++ & ++ \\
\hline NAF & +++ & _ & +++ & +++ & +++ & +++ & +++ & +++ & +++ & +++ & + & +++ & - \\
\hline
\end{tabular}

Source-Experimental results

- indicated absent, + indicated present, ++ indicated moderate present, +++ indicated high present 
The results of the various phytochemical screening tests obtained during the experiment are shown in Table 2. Tannin, quinine, terpenoid, flavonoid, steroid, alkaloid, cardiac glycoside, glycoside, volatile oils, etc were the phytoconstituents found in plants. According to the literature and the tally done with the obtained result, Curcumin present in turmeric has reported improved insulin resistance, glucose uptake, effected in blood pressure, and reduced inflammation (Azhdari et al. 2019). Flavonoid caused risk reduction mainly from cardiovascular diseases and cancer (Ballard \& Marostica, 2019). The presence of classes of phytochemicals as such; flavonoid, alkaloid, tannin showed cytotoxic effect (Chowdhury et al. 2017). The color and aroma imparting flavonoids were stated to show anticancer properties. Additionally, cholesterol-lowering, as well as cytotoxic qualities, anti-bacterial, anti-viral properties, are credited to the presence of saponin (Bailly \& Vergoten, 2020). Tannin shows an anticancer property that is perceptible from its inhibitory activity towards growth (Mazni, ho Yin, Azizul, \& Nurdin, 2016). Plants containing a high amount of flavonoids could be useful as anti-bacterial (Ballard \& Marostica, 2019). So the plants like Zingiber, Curcuma, and Acorus could be used as antibacterial, antiseptic agents. The plants containing phenolic compounds could be useful as an antioxidant. Quinine showed antipyretic property so the plants containing quinine like Ocimum, Nyctanthes, Mentha, etc could be used to reduce fever. Mentha is also used as a soothing agent, for relieving toothache, and also as an anti-bacterial anti-helmintic agent (Patil \& Godghate, 2016). Nyctanthes, Zingiber also plays a role in maintaining blood sugar. Zingiber, Acorus, Curcuma consisted more amount of more cardiac glycoside which is beneficial for the heart. The phenolic compound, tannin, terpenoid, flavonoids possess an anti-helmintic property so the plant Zanthoxylum, Acorus could be used to treat stomach problems (Nath \& Yadav, 2016). The polyphenolic compounds, flavonoid, terpenoid found in Allium cepa, and Allium sativum is useful as an antioxidant, anti-inflammatory, antibacterial agent. Likewise, they play an important role in reducing blood pressure, in preventing heart diseases.

\section{Study of the effect of plant extracts in the germination of Pisum sativum seeds:}

According to the observation germination of seed in water was with shoot length $0.9 \mathrm{~cm}$. Water and methanol was used as positive control and negative control respectively. The observed results in the aqueous extract, methanol extract are shown in Table 3 . The inhibition in growth in 
the aqueous extract may be due to the presence of phytoconstituents. In the methanol extract of the plant sample, the seeds did not germinate. The table below indicated the length of shoot of the seeds in aqueous and methanol extract which was the obtained result for determining the cytotoxic effect of the extracts.

Table 3: Shoot growth in the extracts

\begin{tabular}{lllllllllll}
\hline Plant Extract & ACB & CLR & OSL & MAL ASB & ZOR & ACR & ZAS & NAL & NAF \\
\hline $\begin{array}{l}\text { Shoot growth in aqueous } \\
\text { extract }(\mathrm{cm})\end{array}$ & 0.2 & 0.2 & 0.3 & 0.2 & 0.2 & 0.2 & 0.3 & 0.3 & 0.3 & 0.3 \\
\hline
\end{tabular}

Source-Experimental Result

Shoot growth in methanol extract : - ve Shoot growth in water: $0.9 \mathrm{~cm}$

This result revealed that the phytoconstituents in plant extracts showed a cytotoxic effect in the germinating Pisum sativum seeds. Hence these plants can be further studied and experimented with to develop drugs against cancer cells and also may be against microbes and bacteria.

\section{CONCLUSIONS}

Hence, the phytochemical screening of the selected plant sample was done. From the study, it could be concluded that plants are a great source of phytochemicals that could be utilized in curing various ailments. Tannin, quinine, terpenoid, flavonoid, steroid, alkaloid, cardiac glycoside, glycoside, volatile oils, etc were the phytoconstituents present abundantly in plants.

Phytochemical screening played an important role in identifying various phytoconstituents present in plant extracts. Phytochemicals in the aqueous extract slightly inhibited the growth. This study helped to know the cytotoxic effect of the phytoconstituents present in plant extracts on the living cells.

The study provided an important basis for further investigation into the isolation and characterization of phytoconstituents from the selected plants for the development of drugs. The study was only based on qualitative analysis and screening. It would be better if a quantitative detection, their bioactivity, and IR spectra of the various phytochemicals could be performed. The study would be more beneficial if the detection, analysis, and separation of the phytoconstituents could be done. 


\section{ACKNOWLEDGMENTS}

The authors would like to acknowledge the Department of Chemistry, Bhaktapur Multiple Campus for providing the facilities to perform the research work. We would also like to thank the reviewer for valuable comments and suggestions.

\section{REFERENCES}

Alamzeb, M., Khan, M.R., Ali, S., Shah, S.Q., \& Mamoon, U.R. (2013). Antimicrobial properties of extracts and compounds isolated from Berberis jaeschkeana, Bangladesh J Pharmacol., 8(2): 107-109. https://doi.org/10.3329/bjp.v8i2.13551, Accessed: 19.01.2018.

Arwande, J.O., Akinnusotu, A., \& Alademeyin, J.O. (2018). Extractive value and phytochemical screening of ginger (Zingiber officinale) and turmeric (Curcuma longa) using different solvents. Intl. J. Trad. Nat. Med., 8(1): 13-22. www.ModernScientificPress.com/ Journals/ IJTNM.aspx, Accessed: 12.11. 2020

Azhdari, M., Karandish, M., \& Mansoori, A. (2019). Metabolic benefits of curcumin supplementation in patients with metabolic syndrome: A systematic review and meta-analysis of randomized controlled trials. Phytotherapy Research, 33(5): 1289-1301, https:// doi. org/10.1002/ ptr.6323, Accessed: 04.11.2020.

Bailly, C., \& Vergoten, G. (2020). Esculentosides: Insights into the potential health benefits, mechanism of action, and molecular target. Phytomedicine 79. https://doi.org/10.1016/j.phymed.2020.153343, Accessed: 04.11.2020.

Ballard, C.R., \& Marostica, M.R. (2019). Health benefits of flavonoid., in book Bioactive Compounds, 185-201. https://doi.org/10.1016/ b978-0-12-814774-0.00010-4, Accessed: 04.11.2020

Batiha, G.E. \& Beshbishy, A.M. (2020). Gas chromatography-mass spectrometry analysis, phytochemical screening and anti-protozoal effects of the methanolic Viola tricolor and acetonic Laurus nobilis extracts, BMC Complementary Medicine and Therapies, 20(87). https://doi.org/10.1186/s12906-020-2848-2, Accessed: 01.11.2020.

Bharti, S.; \& Bhushan, B. (2015). Phytochemical and pharmacological activities of Zanthoxyllum armatum. DC: An Overview. Res. J. Pharm. Biol. Chem. Sci., 6(5): 1403-1409. http://rjpbcs.com/.../ [194].pdf, Accessed: 01.11.2018. 
Carroll, R.E., Benya, R.V.,Turgeon, D.K.,Vareed, S., Neuman, M., \& Rodriguez, I. (2011). Phase clinical trial of curcumin for the prevention of colorectal neoplasia. Cancer prevention research, 4(3): 354-364. https://doi.org/10.1158/1940-6207.CAPR-10-0098, Accessed: 17.03.2018.

Chaudhary, A., Sharma, S., Mittal, A., Gupta, S., \& Dua, A. (2020). Phytochemical and antioxidant profiling of Ocimum sanctum . Journal of Food Science and technology., 57(10): 38523863. https://doi.org/10.1007/s13197-020-04417-2, Accessed: 04.01.2021.

Chekuboyina, R.K., \& Rao, D.B. (2015). Assessment of phytochemicals and antioxidant activities of raw and germinating Ceibapentandra (kapok) seeds. J. Biomed. Res. 29 (5): 414-419. https://doi.org/10.7555/JBR.27.20120145 Corpus ID: 18444612, Accessed: 06.07.2018.

Chowdhury, S., Poddar, S.K., Zaheen, S., Noor, F.A, Ahmed, N., Haque, S., \& Akbar, N. (2017). Phytochemical screening and evaluation of cytotoxic and hypoglycemic properties of Mangifera indica Peels. Asian Pacific J. Trop. Biomed., 7(1): 49-52. https://doi. org/10.1016/j.apjtb.2016.09.009, Accessed: 08.08.2018.

Handa, S.S., Khanuja, S.P.S., Longa, G., \& Rakesh, D.D. (2008). Extraction Technologies for Medicinal and Aromatic Plants ( $1^{\text {st }}$ Edition) P. 66, Italy: United Nations industrial development organization and international centre for science and high technology.

Haque, M.M., Sultana, N., Abedin, SMT., \& Kabir, S.E. (2019). Phytochemical screening and determination of minerals and heavy metals in the flowers of Nyctanthes arbortristis L. Bangladesh J. Sci. Indl .Res., 54(4): 321-328. https://doi.org/10.3329/bjsir. v54i4.44566, Accessed: 12.05. 2020.

Hassan, S.A., \& Samy, A.A. (2007).Allelopathic effect of Calotropisprocera leaves extract on seed germination of some plants, Science Journal, 19(1): 115-126 https://doi.org/10.4197/Sci.19-1.9 Corpus ID: 55860284, Accessed: 17.08.2018.

Maithilikarpagaselvi, N., Sridhar,M.G., \& Sripradha, R. (2020). Evaluation of free radical scavenging activities and phytochemical screening of Curcuma longa extracts. Journal of young pharmacists, 12(2): 113. 
Mazni Abu, Z., ho Yin, W., Azizul, I., \& Nurdin, A. (2016). Antioxidant, antimicrobial and cytotoxic potential of condensed tannin from Leucaena leucocephala Hybrid Rendang. Food Sci. Hum. Wellness, 5(2): 65-75. https://doi.org/10.10161J.fshw.2016.02.001, Accessed: 05.11.2018.

Melania, P., Natalia, P., \& Lodivicus,C. (2019). Phytochemical screening and anti-oxidant effectiveness of garlic (Allium sativum) from Timor island. J.Bio\& Biol Edu., 11 (1): 1-7. http://dx.doi.org/10.15294/ boisaintifika.vllil.17313, Accessed: 17.11. 2020.

Mercy, A.G., Light, W.F., \& Gospel, SA. (2017). Qualitative and quantitative phytochemical screening of some plants used in ethnomedicine in the Niger Delta region of Nigeria, Journal of food and Nutrition Sciences, 5(5): 198-205 https://doi.org/10.11648/j. jfns.20170505.16, Accessed: 08.09.2018.

Mishra, A., Sharma, A.K, Kumar, S, Saxena, A.K. \& Pandey, \& A.K. (2013). Bauhinia variegate leaf extracts exhibit considerable antibacterial, antioxidant and anticancer activity; Bio Med Research International; 2013: 1-10. https://doi.org/10.1155/2013/915436, Accessed: 05.01.2018.

Molyneux., R.J., Lee, S.T., Gardener, L.E.,\& Panter K.E. (2007). Phytochemicals: The good, the bad, and the ugly? Phytochem, 68 (2224): 2973-2985. https://doi.org/10.1016/j.phytochem.2007.09.004, Accessed: 05.05.2018.

Nath, P., \& Yadav, A.K. (2016). Anthelmintic activity of a standardized extract from the rhizomes of Acorus Calamus Linn. (Acoraceae) Against Experimentally Induced Cestodiasis in Rats, $J$ Intercult Ethnoparmacol, 5(4): 390-395. https://doi.org/10.5455/ jice.20160521124439, Accessed: 20.09.2018.

Oladeji, O.S., Odelade K.A., \& Oloke, K. (2019). Phytochemical screening and anti-microbial investigation of Moringa oleifera leaf extract. African Journal of Science and Technology, Innovation, and Development, 12(1): 79-84. https://doi.org/10.1080/20421338.201 9.1589082, Accessed: 04.11.2020.

Patil, S.K., Patil, R.S., \& Godghate, A.G. (2016). Mentha; phytochemical, antibacterial, and dipterian adulticidal approach. Int. J. Pharmacol. Sci., 8(3): 352-355. http://creative commonsorg/licenses/by/4.0/, Accessed: 03.04.2018. 
Radwan, A.M., Alghamdi, H.A., Kenawy, \& Sahar, K.M. (2019). Effects of calotropisprocera L. plant extract on seed germination and growth of microorganisms, Annual of Agri. Sci., 64(2): 183-187. https:// doi.org/10.1016/j.aoas.2019.12.001. Accessed: 04.11.2020.

Talukdar, A., \& Chaudhary, B. (2010). Phytochemical Screening of ethanolic extracts of Rubia Cordiofolia. Pharm. Biol. Sci., 1(4): 530-536.

Thusa, R., \& Mulmi, S. (2017) Analysis of phytoconstituents and biological activities of different parts of Mahonia nepalensis and Berberis aristata, Nepal Journal of Biotechnology, 5: 5-13. https://doi.org/ 10.3126/njb.v5i1.18864, Accessed: 05.02.2018. 